\title{
Computed tomography of the abdomen of calves during the first 105 days of life: III. Urinary tract and adrenal glands
}

Braun, Ueli ; Schnetzler, Charlotte ; Augsburger, Heinz ; Bettschart-Wolfensberger, Regula ; Ohlerth, Stefanie

\begin{abstract}
Computed tomographic (CT) findings of the urinary tract and adrenal glands of five healthy male calves in the first 105 days of life were compared with corresponding cadaver slices. The structures seen on CT images were identified using the corresponding cadaver slices. CT produced exact images of the kidneys, urinary bladder, urethra and adrenal glands, but reliable images of the ureters were only obtained near the renal hilus. There was excellent agreement between the structures on the CT images and the tissue slices. The structure and vessels of the kidneys, the origin of the ureters, the location, size and content of the urinary bladder and the course of the urethra in the pelvis and penis were evident on images. The size and volume of the kidneys and the length and width of the adrenal glands increased significantly during the study, but the ureteral and urethral diameters changed little.
\end{abstract}

DOI: https://doi.org/10.1024/0036-7281/a000583

Posted at the Zurich Open Repository and Archive, University of Zurich

ZORA URL: https://doi.org/10.5167/uzh-98724

Journal Article

Accepted Version

Originally published at:

Braun, Ueli; Schnetzler, Charlotte; Augsburger, Heinz; Bettschart-Wolfensberger, Regula; Ohlerth, Stefanie (2014). Computed tomography of the abdomen of calves during the first 105 days of life: III. Urinary tract and adrenal glands. Schweizer Archiv für Tierheilkunde, 156(5):237-247.

DOI: https://doi.org/10.1024/0036-7281/a000583 
1 Computed tomography of the abdomen of calves during the first 105 days of life: III. Urinary tract and adrenal glands

\author{
U. Braun ${ }^{1}$, C. Schnetzler ${ }^{1}$, H. Augsburger ${ }^{2}$, R. Bettschart ${ }^{3}$, S. Ohlerth ${ }^{4}$
}

${ }^{1}$ Department of Farm Animals, ${ }^{2}$ Institute of Veterinary Anatomy, ${ }^{3}$ Division of Anaesthesiology and ${ }^{4}$ Division of Diagnostic Imaging, Vetsuisse Faculty, University of Zurich

\title{
Summary
}

Computed tomographic (CT) findings of the urinary tract and adrenal glands of five healthy male calves in the first 105 days of life were compared with corresponding cadaver slices. The structures seen on CT images were identified using the corresponding cadaver slices. CT produced exact images of the kidneys, urinary bladder, urethra and adrenal glands, but reliable images of the ureters were only obtained near the renal hilus. There was excellent agreement between the structures on the CT images and the tissue slices. The structure and vessels of the kidneys, the origin of the ureters, the location, size and content of the urinary bladder and the course of the urethra in the pelvis and penis were evident on images. The size and volume of the kidneys and the length and width of the adrenal glands increased significantly during the study, but the ureteral and urethral diameters changed little.

Keywords: computed tomography, cattle, calf, urinary tract, kidney, urinary bladder, ureter, urethra, adrenal glands

\section{Computertomographie des Abdomens von Kälbern vom ersten bis zum 105. Lebenstag: III.}

\section{Harnapparat und Nebennieren}

In der vorliegenden Arbeit werden die computertomographischen (CT) Befunde an Harnapparat und Nebennieren von 5 gesunden männlichen Kälbern von der Geburt bis zum Alter von 105 Tagen beschrieben und mit denjenigen der postmortalen Untersuchung verglichen. Nieren, Harnblase, Urethra und Nebennieren konnten computertomographisch exakt dargestellt werden, während die Ureteren nur im Bereich des Hilus renalis zuverlässig identifiziert werden konnten. Die Topographie der Organe bzw. der Strukturen und der anatomischen Schnittpräparate stimmten sehr gut überein. An den Nieren waren die Struktur und die Blutgefässe, an den Ureteren deren 
Anfangsteil, an der Harnblase Lage, Grösse und Inhalt und an der Urethra der Verlauf im Becken und Penis zu sehen. Die Ausdehnung und das Volumen der Nieren nahmen von der ersten bis zur sechsten Untersuchung signifikant zu. Das Gleiche gilt für die Länge und Breite der Nebennieren, während sich die Durchmesser von Ureteren und Urethra kaum veränderten.

Schlüsselwörter: Computertomographie, Rind, Kalb, Harnapparat, Niere, Harnblase, Ureter, Urethra, Nebennieren

\section{Introduction}

Computed tomography (CT) is an established imaging modality for the examination of the urinary tract in cats and dogs. It has also been used to study the urinary tract in adult goats by comparing transverse, dorsal and sagittal CT images with corresponding anatomical cadaver slices (Irmer, 2010; Braun et al., 2011c). Diagnostic procedures in calves with suspected urinary tract disorders include clinical examination, urinalysis, haematological analyses, radiography, cystoscopy (in nanny goats) and ultrasonography (Weisser, 2000). Computed tomography is indispensable for the diagnosis of urinary tract disorders in humans (Dobry and Danuser, 2009) and small animals. Because there have been no CT studies of the urinary tract in calves, the goal of this investigation was to document CT findings of the urinary tract in five healthy male calves in the first 105 days of life and to compare the findings with corresponding anatomical cadaver slices.

\section{Animals, Material and Methods}

See communication I.

\section{Kidneys}

Depending on which plane provided the best images, the maximum length of the kidneys was determined in the sagittal or dorsal plane by measuring the distance between the cranial and caudal poles. The same plane was used to measure the maximum width of the kidneys, defined as the distance between the hilus and the lateral border. Multiple transverse sections were used to calculate the kidney volume (in $\mathrm{cm}^{3}$ ) and to determine the parenchymal density in a 4- $\mathrm{cm}^{2}$ area between the hilus and the lateral border (in HU) as described in detail (Schnetzler, 2012).

\section{Ureters}


The diameter of both ureters was measured near the kidney in the plane that provided the best images of the structures.

\section{Urinary bladder}

The distance between the apex of the bladder and the pelvic brim was measured in the sagittal plane. The density of the urine was determined in a $5-\mathrm{cm}^{2}$ area $5 \mathrm{~mm}$ from the bladder wall.

\section{Urethra}

The urethral diameter was measured in the transverse plane.

\section{Adrenal glands}

The maximum length and width of the adrenal glands were measured in the plane that provided the best images of these organs.

\section{Results}

All structures in the CT images could be accurately identified based on transverse, sagittal and horizontal anatomical cadaver sections (Fig. 1, 2). Visual comparison of the CT images with the corresponding cadaver slices was made in the transverse plane at each vertebra from the 6th thoracic vertebra to the middle part of the sacrum (Schnetzler, 2012).

\section{Kidneys}

Both kidneys were easily identified in all calves based on the unique pattern afforded by the reniculi. Contrast enhancement rendered the kidneys hyperdense relative to the surrounding tissue. The density of the renal cortex was greater than that of the medulla, and the renal pelvis was hypodense.

\section{Left kidney}

The left kidney extended from the 3rd lumbar vertebra to the sacrum but could only be identified consistently at the level of the 5th lumbar vertebra (Fig. 3). In all calves, it was seen from the 4th to the 6th lumbar vertebra at the first examination and from the 5th and 6th lumbar vertebra in the last examination. During the study period, it became displaced by the expanding dorsal sac of the rumen from the left side toward the median or sometimes into the right hemiabdomen (Fig. 4). In the dorsal 
and sagittal planes, the left renal artery was seen running from the aorta to the kidney and in the right paramedian region, the left renal vein was observed running from the kidney to the caudal vena cava (Fig. 5, 6). Both blood vessels appeared as straight structures and were only a few centimetres in length. They had a cranioventral course to the renal hilus until the age of three weeks, when it changed to a craniodorsal course relative to the left kidney. The latter change was the result of displacement of the kidney to the right paramedian region by the rumen accompanied by a rotation of the renal hilus. The ureter was seen exiting from the hilar region. The left kidney underwent significant growth during the study period; it was $10.8 \mathrm{~cm}$ long and $6.0 \mathrm{~cm}$ wide at the first examination and $14.6 \mathrm{~cm}$ long and $7.1 \mathrm{~cm}$ wide at the last examination $(\mathrm{P}<0.05)$ (Tab. 1). During the same time period, the mean volume increased from 149.4 to $307.5 \mathrm{~cm}^{3}(\mathrm{P}<0.05)$. The mean parenchymal density decreased significantly from 42.8 to $27.2 \mathrm{HU}$ during the same period.

\section{Right kidney}

The right kidney was imaged from the 13th thoracic to the 6th lumbar vertebra (Fig. 7) but could only be seen consistently at the level of the 3rd lumbar vertebra. It was seen in all calves at the level of the 3rd and 4th lumbar vertebrae at the first examination and from the 2nd thoracic to 3rd lumbar vertebra at the last examination. It was located retroperitoneally, embedded in perirenal fat, always in the right hemiabdomen cranial to the left kidney and in contact with the liver in the renal depression (Fig. 8 - 10). It appeared oval in all planes. As for the left kidney, the right renal artery and vein were seen medially. The hilus and ureter exiting from the left kidney were directed ventromedially. The length, width, volume and density of the right and left kidneys were similar (Tab. 2).

\section{Ureters}

The renal attachment of the ureter at the hilus was always seen in the right kidney $($ Fig. 8, 9) and in over $80 \%$ of examinations of the left kidney. Both ureters ran caudally in a dorsomedial direction but were only occasionally identified; their site of entry into the urinary bladder was also not usually seen. The left and right ureters had similar diameters, which measured $0.3 \mathrm{~cm}$ on average at the first examination and 0.5 and $0.7 \mathrm{~cm}$, respectively, at the last examination (Tab. 1, 2).

\section{Urinary bladder}


The urinary bladder was identified as an oval to circular structure at the level of the sacrum on the pelvic floor beneath the uterus at all examinations (Fig. 11). Depending on the degree of fill it reached beyond the pelvic brim into the abdomen.

\section{Urethra}

The urethra was seen exiting from the neck of the urinary bladder in all three planes. It ran caudally below the rectum to the ischiadic arc, where it turned back cranioventrally and continued along the penis to the tip of the penis in the prepuce (Fig. 12,13). The mean urethral diameter was $1.5 \mathrm{~cm}$ at the first examination and $1.7 \mathrm{~cm}$ at the last examination (Tab. 3).

\section{Adrenal glands}

The adrenal glands were best seen in the transverse plane and appeared as oval to bean-shaped structures. The left adrenal gland was located at the level of the cranial pole of the left kidney in the immediate vicinity of the renal vessels (Fig. 6 A). It was exactly in the median and ventral to the aorta and the caudal vena cava. The right adrenal gland was located medial to the hilus of the right kidney and immediately cranial to or between the renal vein and artery (Fig. 14, 15). From the first to the last examination, the mean length of the left adrenal gland increased from 1.01 to $1.53 \mathrm{~cm}$ and the width from 0.66 to $0.91 \mathrm{~cm}$ (Tab. 4); similar increases were recorded for the right adrenal gland.

\section{Discussion}

The kidneys were readily identified in calves at all ages because of their unmistakable shape, the unique structure of the reniculi and the strong contrast enhancement. Differentiation of neighbouring organs was also aided by the surrounding hypodense perirenal fat. The size and volume of the kidneys of newborn calves were the same as those of adult goats (Braun et al., 2011c), but increased considerably by the age of 105 days. The length, width and volume of the left kidney of goats were on average $9.3 \mathrm{~cm}, 5.0 \mathrm{~cm}$ and $154.9 \mathrm{~cm}^{3}$, respectively (Braun et al., 2011c), compared with $14.6 \mathrm{~cm}, 7.1 . \mathrm{cm}$ and $307.5 \mathrm{~cm}^{3}$ in 105 -day-old calves. There was considerable individual variation in the density of the renal parenchyma, but there were no differences between the kidneys of individual calves. This is in agreement with the results of CT of human kidneys, in which the parenchyma appeared relatively homogeneous and had a density of 30 to $50 \mathrm{HU}$ (Sagel et al., 2002). The renal density of the calves at the last examination (27.2 HU left, $30.1 \mathrm{HU}$ right) was similar to that of adult goats (18.5 to $39.5 \mathrm{HU})$. A difference in density between paired kidneys of 
more than $5 \mathrm{HU}$ indicates urolithiasis in human medicine (Goldman et al., 2004). Computed tomography is the diagnostic technique of choice in people with suspected pyelonephritis (Craig et al., 2008), kidney tumours (Dobry and Danuser, 2009; Griffin et al., 2009) and kidney trauma (Lee et al., 2007), and is indispensible for the examination of patients with renal colic attributable to urolithiasis (Jindal and Ramchandani, 2007). It is likely that CT will improve the diagnosis of urinary tract diseases in calves.

The ureters were seen at the hilus of the right kidney in all scans and at the hilus of the left kidney in $80 \%$ of scans, but their course to and junction with the urinary bladder were only occasionally seen, in contrast to CT scans in goats (Braun et al., 2011c). We assume that dilated or otherwise diseased ureters would also be visible on CT scans in calves.

In contrast to the ureters, the urinary bladder and urethra were always seen at the level of the sacrum. Omphaloarteritis, omphalourachitis and various other urachal abnormalities are common problems in calves and can be diagnosed quite reliably using ultrasonography (Lischer and Steiner, 1993, 1994; Lischer et al., 1994). Computed tomography should further improve images of umbilical and urachal disease processes and facilitate the planning of the surgical treatment. While ultrasonographic imaging of the urinary bladder is straightforward, imaging of the urethra of bull calves is much more difficult and reports are scant (Weisser, 2000); the penile urethra was only vaguely seen during urination. Concrement in the urethra is readily seen on radiographs and should also be visible on CT images.

Unlike the umbilical vein, which could be seen on CT scans until the age of three weeks (communication I), the umbilical artery was never identified caudal to the umbilicus, which was in agreement with ultrasonographic findings (Lischer, 1991; Watson et al., 1994).

The adrenal glands were reliably seen on CT scans, although their measurements varied greatly. Measurements of smaller structures are less precise than those of larger ones (Voorhout, 1990), but also depend on the position of the organ relative to the tomographic plane (Voorhout, 1990). The adrenal glands did not grow significantly during the study period and their size at the age of 105 days corresponded to measurements obtained in adult goats and dogs (Assheuer and Sager, 1997; Braun et al., 2011c). In the calf, adrenal disease is rare and CT examination of the adrenal glands is of little clinical importance. This is in contrast to the goat, in which adrenal cortical adenoma (Smith and Sherman, 2009), medullary phaeochromocytoma (De Gritz, 1997) and adrenal hypocortisolism (Swart et al., 1996; Engelbrecht et al., 2000) have been reported, although adrenal disease is generally considered to be rare. 
Conclusions

194

This study has shown that CT is very useful for the examination of the urogenital tract of calves. The transverse, horizontal and sagittal cadaver sections were essential for identification of the structures on CT images. This study provides reference values for CT examination of calves with suspected diseases of the urinary tract and adrenal glands.

\section{References}

Ahvenjärvi, S., Skiba, B. Huhtanen, P.: Effect of heterogenous digesta chemical composition on the accuracy of measurements of fiber flow in dairy cows. J. Anim. Sci. 2001, 79: 1611-1620.

Assheuer, J., Sager, M.: MRI and CT Atlas of the Dog. Blackwell Science, Berlin 347-421, 1997.

Becker, M., Heun, C., Tsousis, G., Bollwein, H.: Application of computed tomography for the evaluation of obstetrically relevant measurements in German Holstein-Friesian calves. Theriogenology 2011, 75: 1052-1056.

Braun, U., Marmier, O.: Ultrasonographic examination of the small intestine of cows. Vet. Rec. 1995, 136: 239-244.

Braun, U., Amrein, E.: Ultrasonographic examination of the caecum and the proximal and spiral ansa of the colon of cattle. Vet. Rec. 2001, 149: 45-48.

Braun, U., Blessing, S.: Ultrasonographic examination of the omasum in 30 healthy cows. Vet. Rec. 2006, 159: 812-815.

Braun, U.: Ultrasonography of the gastrointestinal tract in cattle. Vet. Clin. North Am. (Food Anim. Pract.) 2009, 25: 567-590.

Braun, U., Irmer, M., Augsburger, H., Jud, R., Ohlerth, S.: Computed tomography of the abdomen in Saanen goats: I. Reticulum, rumen and omasum. Schweiz. Arch. Tierheilk. 2011a, 153: 307-313. 
Braun, U., Irmer, M., Augsburger, H., Müller, U., Jud, R., Ohlerth, S.: Computed tomography of the abdomen in Saanen goats: II. Liver, spleen, abomasum, and intestine. Schweiz. Arch. Tierheilk. 2011b, 153: 314-320.

Braun, U., Irmer, M., Augsburger, H., Ohlerth, S.: Computed tomography of the abdomen in Saanen goats: III. Kidneys, ureters and urinary bladder. Schweiz. Arch. Tierheilk. 2011c, 153: 321329.

Braun, U., Gautschi, A.: Ultrasonography of the reticulum, rumen, omasum and abomasum in 10 calves before, during and after ingestion of milk. Schweiz. Arch. Tierheilk. 2012, 154: 287-297.

Braun, U., Gautschi, A., Tschuor, A., Hässig, M.: Ultrasonography of the reticulum, rumen, omasum and abomasum before, during and after ingestion of hay and grass silage in 10 calves. Res. Vet. Sci. 2012, 93: 1407-1412.

Braun, U., Schweizer, A., Trösch, L.: Ultrasonography of the rumen of dairy cows. BMC Vet. Res. 2013, 9:44.

Breiman, R. S., Beck, J. W., Korobkin, M., Glenny, R., Akwari, O. E., Heaston, D. K., Moore, A. V., Ram, P. C.: Volume determinations using computed tomography. Am. J. Roentgenol. 1982, 138: 329-333.

Buczinski, S., Duval, J., D'Anjou, M. A., Francoz, D., Fecteau, G.: Portocaval shunt in a calf: Clinical, pathologic, and ultrasonographic findings. Can. Vet. J. 2007, 48: 407-410.

Craig, W. D., Wagner, B. J., Travis, M. D.: Pyelonephritis: radiologic-pathologic review. Radiographics 2008, 28: 255-277.

De Gritz, B. G.: Hereditary caprine phaeochromocytoma. Zbl. Vetmed. A 1997, 44: 313-316. 
Dirksen, G.: Krankheiten von Haube und Pansen bei Milchkalb und Jungrind. In: Innere Medizin und Chirurgie des Rindes. Hrsg. G. Dirksen, H.-D. Gründer, M. Stöber. Parey Buchverlag, Berlin, 2002, 455-469.

Dobry, E., Danuser, H.: Bildgebung der Nieren und Harnwege. Ther. Umsch. 2009, 66: 39-42.

Engelbrecht, Y., Herselman, T., Louw, A., Swart, P.: Investigation of the primary cause of hypoadrenocorticism in South African angora goats (Capra aegagrus): a comparison with Boer goats (Capra hircus) and Merino sheep (Ovis aries). J. Anim. Sci. 2000, 78: 371-379.

Fike, J. R., Druy, E. M., Zook, B. C., Davis, D. O., Thompson, J. E., Chaney, E., Bradley, E. W.: Canine anatomy as assessed by computerized tomography. Am. J. Vet. Res. 1980, 41: 1823-1832.

Flöck, M.: Ultraschalldiagnostik von Entzündungen der Nabelstrukturen, persistierendem Urachus und Umbilikalhernie beim Kalb. Berl. Münch. Tierärztl. Wschr. 2003, 116: 2-11.

Gautschi, A.: Sonographische Untersuchungen an Haube, Pansen, Psalter und Labmagen von 30 Kälbern. Dissertation, Universität Zürich, 2010.

Goldman, S. M., Faintuch, S., Ajzen, S. A., Christofalo, D. M., Araújo, M. P., Ortiz, V., Srougi, M., Kenney, P. J., Szejnfeld, J.: Diagnostic value of attenuation measurements of the kidney on unenhanced helical CT of obstructive ureterolithiasis. Am. J. Roentgenol. 2004, 182: 1251-1254.

Gore, R. M., Balthazar, E. J., Ghahremani, G. G., Miller, F. H.: CT features of ulcerative colitis and Crohn's disease. Am. J. Roentgenol. 1996, 167: 3-15.

Griffin, N., Grant, L. A., Bharwani, N., Sohaib, S. A.: Computed tomography in metastatic renal cell carcinoma. Semin. Ultrasound CT MRI 2009, 30: 359-366.

Heidemann, A., Grunert, E.: Ultraschalldiagnostik als Entscheidungshilfe für das weitere Vorgehen bei Nabelentzündungen des neugeborenen Kalbes. Prakt. Tierarzt 1995, 76: 742-746. 
Hummel, J., K.-H. Südekum, D. Bayer, S. Ortmann, W. J. Streich, J.-M. Hatt, M. Clauss: Physical characteristics of reticuloruminal contents of oxen in relation to forage type and time after feeding. J. Anim. Physiol. Anim. Nutr. 2009, 93: 209-220.

Irmer, M.: Computertomographische Untersuchung des Abdomens bei 30 Ziegen. Dissertation, Universität Zürich, 2010.

James, S., Balfe, D. M., Lee, J. K. T., Picus, D.: Small-bowel disease: Categorization by CT examination. Am. J. Roentgenol. 1987, 148: 863-868.

Jindal, G., Ramchandani, P.: Acute flank pain secondary to urolithiasis: radiologic evaluation and alternate diagnoses. Radiol. Clin. North Am. 2007, 45: 395-410, vii.

Kayaalp, C., Arda, K., Oto, A., Oran, M.: Liver volume measurement by spiral CT: an in vitro study. Clin. Imaging 2002, 26: 122-124.

König, H. E., Sautet, J., Liebich, H.-G.: Anatomie der Haussäugetiere. Schattauer Verlag, Stuttgart, 2005.

Kovács, P. L., Südekum, K. H., Stangassinger, M.: Effects of intake level of a mixed diet on chewing activity and on particle size of ruminated boli, ruminal digesta fractions and faeces of steers. Reprod. Nutr. Dev. 1997, 37: 517-528.

Krüger, S. S.: Sonographische Untersuchungen an Haube, Pansen, Psalter, Labmagen, Milz und Leber von Kälbern von der Geburt bis zum Alter von 100 Tagen. Dissertation, Universität Zürich, 2012.

Lee, Y. J., Oh, S. N., Rha, S. E., Byun, J. Y.: Renal trauma. Radiol. Clin. North Am. 2007, 45: 581592, ix.

Lee, K., Yamada, K., Tsuneda, R., Kishimosto, M., Shimizu, J., Kobayashi, Y., Furuoka, H., Matsui, T., Sasaki, N., Ishii, M., Inokuma, H., Iwasaki, T., Miyake, Y.: Clinical experience of using multidetector-row CT for the diagnosis of disorders in cattle. Vet. Rec. 2009, 165: 559-562. 
Lee, K., Ikeo, S., Kishimoto, M., Shimizu, J., Iwasaki, T., Miyake, Y., Yamada, K.: Use of a saline chaser to reduce the dose of contrast material for dynamic CT in cattle. Vet. Rec. 2010, 167: 170173.

Lischer, C.: Sonographische Darstellung der Nabelinvolution beim Kalb. Dissertation, Universität Zürich, 1991.

Lischer, C. J., Steiner, A.: Ultrasonography of umbilical structures in calves. Part I:

Lischer, C. J., Steiner, A.: Ultrasonography of the umbilicus in calves. Part 2: Ultrasonography,

Noda, T., Todani, T., Watanabe, Y., Yamamoto, S.: Liver volume in children measured by computed 350

Ultrasonographic description of umbilical involution in clinically healthy calves. Schweiz. Arch. Tierheilk. 1993, 135: 221-230.

diagnosis and treatment of umbilical diseases. Schweiz. Arch. Tierheilk. 1994, 136: 227-241.

Lischer, C. J., Iselin, U., Steiner, A.: Ultrasonographic diagnosis of urachal cyst in three calves. J. Am. Vet. Med. Assoc. 1994, 204: 1801-1804.

Lubbers, B. V., Apley, M. D., Coetzee, J. F., Mosier, D. A., Biller, D. S., Mason, D. E., HenaoGuerrero, P. N.: Use of computed tomography to evaluate pathologic changes in the lungs of calves with experimentally induced respiratory tract disease. Am. J. Vet. Res. 2007, 68: 1259-1264.

Mortele, K. J., McTavish, J., Ros, P. R.: Current techniques of computed tomography, helical CT, multidetector CT, and 3D reconstruction. Clin. Liver Dis. 2002, 6: 29-52.

Nickel, R., Schummer, A., Seiferle, E.: Eingeweide. In: Lehrbuch der Anatomie der Haustiere, Vol. 2. Eds. J. Frewein, H. Gasse, R. Leiser, H. Roos, H. Thomé, B. Vollmerhaus, H. Waibl. Parey Buchverlag, Stuttgart, 2004, 103-434. tomography. Pedriatr. Radiol. 1997, 27: 250-252. 
Nuss, K., Schnetzler, C., Hagen, R., Schwarz, A., Kircher, P.: Klinische Anwendung der Computertomographie beim Rind. Tierärztl. Prax. 2011, 39 (G): 317-324.

Radostits, O. M., Gay, C. C., Hinchcliff, K. W., Constable, P. D.: Veterinary Medicine. A Textbook of the Diseases of Cattle, Horses, Sheep, Pigs, and Goats. Philadelphia, Saunders Elsevier, 2007.

Rivero, M. A., Vázquez, J. M., Gil, F., Ramírez, J. A., Vilar, J. M., De Miguel, A., Arencibia, A.: CT-soft tissue window of the cranial abdomen in clinically normal dogs: An anatomical description using macroscopic cross-sections with vascular injection. Anat. Histol. Embryol. 2009, 38: 18-22.

Sagel, S. S., Stanley, R. J., Levitt, R. G., Geisse, G.: Computed tomography of the kidney. 1977. J. Urol. 2002, 167: 458-468.

Salomon, F.-V., Geyer, H., Gille, U.: Verdauungsapparat. In: Anatomie für die Tiermedizin. Enke Verlag, Stuttgart, 2008, 235-323.

Samii, V. F., Biller, D. S., Koblik, P. D.: Normal cross-sectional anatomy of the feline thorax and abdomen: comparison of computed tomography and cadaver anatomy. Vet. Radiol. Ultrasound 1998, 39: 504-511.

Schnetzler, C.: Computertomographische Untersuchung des Abdomens von Kälbern von der Geburt bis zum Alter von 105 Tagen. Dissertation, Universität Zürich, 2012.

Schnorr, B., Kressin, M.: Entwicklung der Verdauungsorgane. In: Embryologie der Haustiere. Enke Verlag, Stuttgart, 2011, 161-185.

Steiner, A., Lischer, C. J., Oertle, C.: Marsupialization of umbilical vein abscesses with involvement of the liver in 13 calves. Vet. Surg. 1993, 22: 184-189.

Stieger, S. M., Zwingenberger, A., Pollard, R. E., Kyles, A. E., Wisner, E. R.: Hepatic volume estimation using quantitative computed tomography in dogs with portosystemic shunts. Vet. Radiol. Ultrasound 2007, 48: 409-413. 
Smith M. C., Sherman, D. M.: Goat Medicine. Wiley-Blackwell, 2009. 625-802.

Swart, P., Engelbrecht, Y., Herselmann, T.: An investigation of hypo-adrenocorticism in Angora goats. Endocr. Res. 1996, 22: 563-565.

Teixeira, M., Gil, F., Vazquez, J. M., Cardoso, L., Arencibia, A., Ramirez-Zarzosa, G., Agut, A.: Helical computed tomographic anatomy of the canine abdomen. Vet. J. 2007, 174: 133-138.

Thrall, D. E.: Textbook of Veterinary Diagnostic Radiology. W. B. Saunders, Philadelphia, 2007,

Tschuor, A., Clauss, M.: Investigations on the stratification of forestomach contents in ruminants: an ultrasonographic approach. Eur. J. Wildl. Res. 2008, 54: 627-633.

Urata, K., Kawasaki, S., Matsunami, H., Hashikura, Y., Ikegami, T., Ishizone, S., Momose, Y., Komiyama, A., Makuuchi, M.: Calculation of child and adult standard liver volume for liver transplantation. Hepatology 1995, 21: 1317-1321.

Voorhout, G.: X-ray-computed tomography, nephrotomography, and ultrasonography of the adrenal glands of healthy dogs. Am. J. Vet. Res. 1990, 51: 625-631.

Watson, E., Mahaffey, M. B., Crowell, W., Selcer, B. A., Morris, D. D., Seginak, L.:

Ultrasonography of the umbilical structures in clinically normal calves. Am. J. Vet. Res. 1994, 55: 773-780.

Weisser, P.: Sonographische Befunde am Harnapparat des gesunden Kalbes im Alter von 1 bis 6 Monaten. Dissertation, Universität München, 2000.

\section{Correspondence}

Ueli Braun, Departement für Nutztiere, Winterthurerstrasse 260, CH-8057 Zürich, E-Mail: ubraun@vetclinics.uzh.ch; Fax: ++41 446358904 


\section{Legend to figures}

416 Figure 1: Comparison of a transverse CT image in a soft-tissue window setting (A) and the corresponding anatomical slice (B) at the level of the 3rd lumbar vertebra in a 104-day-old HolsteinFriesian bull calf. 1 Right kidney, 2 Renal sinus, 3 Renal vein, 4 Right ureter, 5 Liver, 6 Rumen, 7 Abomasum, 8 Small intestine, 9 Large intestine, 10 Caudal vena cava, L Left, R Right.

Figure 2: Comparison of a transverse CT image in a soft-window setting (A) and the corresponding anatomical slice (B) at the level of the 6th lumbar vertebra in a 104-day-old Holstein-Friesian bull calf. 1 Left kidney, 2 Left ureter, 3 Caudal vena cava, 4 Aorta, 5 Rumen, 6 Small intestine, 7 Large

Figure 3: Visibility of the left kidney on transverse CT images in five Holstein-Friesian bull calves.

The images were taken at different lumbar vertebrae and the sacrum during six CT scans in the first 104 days of life. The different shades of red indicate the number of calves in which the kidney was

Figure 4: Transverse CT images of the abdomen at the level of the 1st lumbar vertebra in a one-dayold (A) and at the level of the 6th lumbar vertebra in a 104-day-old Holstein-Friesian bull calf (B). 1 Left kidney, 2 Right kidney, 3 Aorta, 4 Left ureter, 5 Rumen, 6 Abomasum, 7 Intestines, L Left, R Right.

Figure 5: Dorsal CT images of the abdomen at the level of the aorta in a 21-day-old (A) and 103440 day-old Holstein-Friesian bull calf (B). 1 Left kidney, 2 Right kidney, 3 Aorta, 4 Left renal vein, 5 Left renal artery, 6 Liver, 7 Spleen, 8 Rumen, 9 Intestines, L Left, R Right.

Figure 6: Sagittal CT images of the abdomen at the level of the left adrenal gland-in a two-day-old (A) and at the level of the caudal vena cava in a 103-day-old Holstein-Friesian bull calf (B). 1 Left kidney, 2 Right kidney, 3 Caudal vena cava, 4 Liver, 5 Left renal vein, 6 Left adrenal gland, 7 Urinary bladder, 8 Abomasum, Cr Cranial, Cd Caudal. 
Figure 7: Visibility of the right kidney on transverse CT images in five Holstein-Friesian bull calves. The images were taken at different thoracic and lumbar vertebrae during six CT scans in the first 105 days of life. The different shades of red indicate the number of calves in which the right kidney was visible at the respective levels. $20 \%, 40 \%, 60 \%, 80 \%$ and $100 \%$, visible in 1, 2, 3, 4 and in all calves, respectively.

Figure 8: Transverse CT image of the abdomen at the level of the 4th lumbar vertebra in a one-dayold Holstein-Friesian bull calf. 1 Right kidney, 2 Right ureter, 3 Caudal vena cava, 4 Aorta, 5 Left kidney, 6 Liver, 7 Abomasum, L Left, R Right.

Figure 9: Dorsal CT image at the level of the aorta in a 104-day-old calf. 1 Right kidney, 2 Aorta, 3 Right renal vein, 4 Left kidney, 5 Urinary bladder, 6 Liver, L Left, R Right.

Figure 10: Sagittal CT image at the level of the right hip joint in a 104-day-old Holstein-Friesian bull calf. 1 Right kidney, 2 Right ureter, 3 Caudal vena cava, 4 Liver, 5 Reticulum, 6 Abomasum, 7 Omasum, 8 Rumen, Cr Cranial, Cd Caudal.

Figure 11: Transverse CT image at the level of the sacrum in a one-day-old Holstein-Friesian bull calf. 1 Urinary bladder, 2 Right ureter, 3 Left ureter, 4 Rectum, L Left, R Right.

Figure 12: Transverse CT image at the level of the pelvis in a two-day-old Holstein-Friesian bull calf. 1 Penis with urethra, 2 Testes, 3 Rectum, L Left, R Right.

Figure 13: Sagittal CT image at the level of the aorta in a 40-day-old Holstein-Friesian bull calf. 1 Urethra, 2 Urinary bladder, 3 Testis, 4 Left kidney, 5 Aorta, Cr Cranial, Cd Caudal.

Figure 14: Transverse CT image at the level of the 2nd lumbar vertebra in a 104-day-old HolsteinFriesian bull calf. 1 Right adrenal gland, 2 Caudal vena cava, 3 Right renal vein, 4 Aorta, 5 Right kidney, 6 Liver, 7 Abomasum, L Left, R Right. 
476 Figure 15: Dorsal CT image at the level of the aorta in a one-day-old Holstein-Friesian bull calf. 1

477 Right adrenal gland, 2 Caudal vena cava, 3 Right renal vein, 4 Aorta, 5 Right kidney, 6 Liver, 7 Left 478 kidney, 8 Spleen, 9 Rumen, L Left, R Right. 
Table 1: CT measurements of the left kidney and left ureter in five Holstein-Friesian bull calves during the first 105 days of life (mean \pm sd, range).

\begin{tabular}{l|c|c|c|c|c|c}
\hline \multirow{2}{*}{ Variable } & \multicolumn{5}{|c}{ Examination } \\
\cline { 2 - 6 } & 1 & 2 & 3 & 4 & 5 \\
\hline Length (cm) & $10.8 \pm 1.05$ & $11.0 \pm 1.72^{\mathrm{a}}$ & $12.2 \pm 1.57^{\mathrm{a}}$ & $13.2 \pm 1.11^{\mathrm{b}, \S}$ & $14.0 \pm 1.13^{\mathrm{b}}$ & $14.6 \pm 1.09$ \\
& $(9.2-11.8)$ & $(9.0-12.6)$ & $(10.4-13.5)$ & $(11.6-14.0)$ & $(12.7-15.5)$ & $(12.8-15.7)$ \\
\hline Width (cm) & $6.0 \pm 0.65$ & $5.9 \pm 1.19^{\mathrm{a}}$ & $7.6 \pm 0.33^{\mathrm{a}, \S}$ & $7.6 \pm 0.57$ & $7.0 \pm 0.93$ & $7.1 \pm 0.91$ \\
& $(5.0-6.7)$ & $(4.8-7.8)$ & $(7.1-8.0)$ & $(7.0-8.5)$ & $(6.0-8.3)$ & $(6.3-8.4)$ \\
\hline Volume $\left(\mathrm{cm}^{3}\right)$ & $149.4 \pm 23.64^{\mathrm{a}}$ & $185.4 \pm 29.51^{\mathrm{a}, \mathrm{b}, \S}$ & $248.3 \pm 26.63^{\mathrm{b}, \mathrm{c}}$ & $310.3 \pm 28.5^{\mathrm{c}}$ & $287.9 \pm 31.97^{\mathrm{d}}$ & $307.5 \pm 32.67^{\mathrm{d}}$ \\
& $(116.5-177.2)$ & $(142.0-224.4)$ & $(217.4-283.7)$ & $(278.4-348.9)$ & $(248.7-332.9)$ & $(272.8-358.0)$ \\
\hline Parenchymal & $42.8 \pm 3.15$ & $44.6 \pm 5.94$ & $38.2 \pm 4.77$ & $38.8 \pm 7.80$ & $30.9 \pm 11.7^{\S}$ & $27.2 \pm 11.81$ \\
density (HU) & $(39.1-46.6)$ & $(34.9-49.2)$ & $(33.7-44.4)$ & $(29.7-50.3)$ & $(14.0-46.4)$ & $(16.6-42.9)$ \\
\hline Ureteral diameter & $0.3 \pm 0.08$ & $0.3 \pm 0.07$ & $0.3 \pm 0.07^{\circ, \mathrm{a}}$ & $0.3 \pm 0.13^{\mathrm{a}}$ & $0.5 \pm 0.34^{\circ}$ & $0.5 \pm 0.12^{\mathrm{o}, \S}$ \\
$(\mathrm{cm})$ & $(0.2-0.4)$ & $(0.2-0.4)$ & $(0.3-0.4)$ & $(0.2-0.6)$ & $(0.3-1.0)$ & $(0.4-0.7)$ \\
\hline
\end{tabular}

480

${ }^{\circ}$ Measured in 4 of 5 calves

a, b, c, d Within rows measurements with identical indices are different $(\mathrm{P}<0.05)$

${ }^{\S}$ First significant difference compared with examination $1(\mathrm{P}<0.05)$ 
Table 2: CT measurements of the right kidney and left ureter in five Holstein-Friesian bull calves during the first 105 days of life (mean \pm sd, range).

\begin{tabular}{l|c|c|c|c|c|c}
\hline \multirow{2}{*}{ Variable } & \multicolumn{5}{|c}{ Examination } \\
\cline { 2 - 6 } & 1 & 2 & 3 & 4 & 5 \\
\hline Length (cm) & $11.8 \pm 1.03$ & $11.9 \pm 1.51^{\mathrm{a}}$ & $12.9 \pm 1.52^{\mathrm{a}, \mathrm{b}, \S}$ & $14.3 \pm 1.17^{\mathrm{b}, \mathrm{c}}$ & $15.0 \pm 1.32^{\mathrm{c}}$ & $15.7 \pm 1.30$ \\
& $(10.2-12.7)$ & $(9.5-13.3)$ & $(10.4-14.2)$ & $(12.5-15.7)$ & $(13.0-16.7)$ & $(13.7-17.0)$ \\
\hline Width (cm) & $6.4 \pm 0.82$ & $6.5 \pm 0.77^{\mathrm{a}}$ & $7.1 \pm 1.10^{\mathrm{a}}$ & $8.0 \pm 0.74^{\S}$ & $7.7 \pm 0.52$ & $8.0 \pm 0.77$ \\
& $(5.4-7.2)$ & $(5.5-7.5)$ & $(5.3-8.3)$ & $(7.3-8.8)$ & $(7.2-8.6)$ & $(7.2-9.2)$ \\
\hline Volume $\left(\mathrm{cm}^{3}\right)$ & $147.5 \pm 20.82^{\mathrm{a}}$ & $179.1 \pm 26.55^{\mathrm{a}, \mathrm{b}, \S}$ & $238.0 \pm 19.08^{\mathrm{b}, \mathrm{c}}$ & $292.4 \pm 17.00^{\mathrm{c}}$ & $270.9 \pm 41.77^{\mathrm{d}}$ & $288.7 \pm 43.22^{\mathrm{d}}$ \\
& $(125.6-182.0)$ & $(143.0-202.4)$ & $(213.3-262.1)$ & $(272.7-317.7)$ & $(225.0-339.2)$ & $(260.1-365.3)$ \\
\hline Parenchymal & $45.2 \pm 1.05$ & $44.4 \pm 5.53$ & $35.9 \pm 6.73^{\S}$ & $34.6 \pm 8.6$ & $30.5 \pm 3.50$ & $30.1 \pm 11.64$ \\
density (HU) & $(44.6-47.1)$ & $(36.4-51.2)$ & $(29.7-44.0)$ & $(23.6-46.2)$ & $(26.8-34.5)$ & $(21.5-48.6)$ \\
\hline Ureteral diameter & $0.3 \pm 0.07$ & $0.3 \pm 0.05$ & $0.4 \pm 0.20$ & $0.4 \pm 0.24$ & $0.6 \pm 0.20^{\S}$ & $0.7 \pm 0.06$ \\
(cm) & $(0.2-0.4)$ & $(0.3-0.4)$ & $(0.3-0.7)$ & $(0.3-0.9)$ & $(0.4-0.8)$ & $(0.6-0.8)$ \\
\hline
\end{tabular}

486

$487 \quad \mathrm{a}, \mathrm{b}, \mathrm{c}, \mathrm{d}$ Within rows measurements with idential indices are different $(\mathrm{P}<0.05)$

$488 \S$ First significant difference compared with examination $1(\mathrm{P}<0.05)$ 
Table 3: CT measuements of the urinary bladder and urethra in five Holstein-Friesian bull calves during the first 105 days of life (mean \pm sd,

490 median, range)

\begin{tabular}{|c|c|c|c|c|c|c|}
\hline \multirow[b]{2}{*}{ Variable } & \multicolumn{6}{|c|}{ Examination } \\
\hline & 1 & 2 & 3 & 4 & 5 & 6 \\
\hline $\begin{array}{l}\text { Distance between } \\
\text { apex of bladder } \\
\text { and pelvic brim }\end{array}$ & $\begin{array}{c}6.5 \pm 3.52 \\
(4.0-12.6)\end{array}$ & $\begin{array}{l}6.1 \pm 1.97 \\
(2.9-7.8)\end{array}$ & $\begin{array}{c}7.3 \pm 2.33 \\
(5.0-10.5)\end{array}$ & $\begin{array}{c}7.9 \pm 4.0 \\
(2.9-12.8)\end{array}$ & $\begin{array}{l}6.4 \pm 1.97^{*} \\
(4.3-8.2)\end{array}$ & $\begin{array}{c}4.4 \pm 0.35^{\#, \S} \\
(4.2-4.7)\end{array}$ \\
\hline $\begin{array}{l}\text { Urinary density } \\
(\mathrm{HU})\end{array}$ & $\begin{array}{c}10.6 \\
(7.4-39.2)\end{array}$ & $\begin{array}{c}9.5 \\
(5.6-15.6)\end{array}$ & $\begin{array}{c}10.8 \\
(-2.7-18.8)\end{array}$ & $\begin{array}{c}7.5 \\
(1.2-37.7)\end{array}$ & $\begin{array}{c}20.0 \\
(-3.0-30.2)\end{array}$ & $\begin{array}{c}27.5^{\#} \\
(21.4-33.5)\end{array}$ \\
\hline $\begin{array}{l}\text { Urethral diameter } \\
(\mathrm{cm})\end{array}$ & $\begin{array}{l}1.5 \pm 0.33 \\
(1.1-1.9)\end{array}$ & $\begin{array}{l}1.5 \pm 0.27 \\
(1.2-1.9)\end{array}$ & $\begin{array}{l}1.4 \pm 0.27 \\
(1.1-1.8)\end{array}$ & $\begin{array}{l}1.6 \pm 0.16 \\
(1.4-1.8)\end{array}$ & $\begin{array}{l}1.5 \pm 0.24 \\
(1.1-1.7)\end{array}$ & $\begin{array}{l}1.7 \pm 0.24^{\circ} \\
(1.5-2.0)\end{array}$ \\
\hline
\end{tabular}

491

$492{ }^{\circ}$ Measured in 4 of 5 calves

$493 *$ Measured in 3 of 5 calves

$494 \quad$ Measured in 2 of 5 calves 
Table 4: CT measurements of the adrenal glands in five Holstein-Friesian bull calves during the first 105 days of life (mean \pm sd, range, all

496 measurements in $\mathrm{cm}$ ).

\begin{tabular}{|c|c|c|c|c|c|c|}
\hline \multirow[b]{2}{*}{ Variable } & \multicolumn{6}{|c|}{ Untersuchung } \\
\hline & 1 & 2 & 3 & 4 & 5 & 6 \\
\hline $\begin{array}{l}\text { Length of right } \\
\text { gland }\end{array}$ & $\begin{array}{c}1.27 \pm 0.23 \\
(0.89-1.45)\end{array}$ & $\begin{array}{c}1.46 \pm 0.46 \\
(0.96-2.06)\end{array}$ & $\begin{array}{c}1.47 \pm 0.32 \\
(1.18-1.95)\end{array}$ & $\begin{array}{l}1.65 \pm 0.26^{\S} \\
(1.30-1.96)\end{array}$ & $\begin{array}{l}1.69 \pm 0.38^{\circ} \\
(1.26-2.04)\end{array}$ & $\begin{array}{c}1.78 \pm 0.31 \\
(1.38-2.13)\end{array}$ \\
\hline $\begin{array}{l}\text { Widht of right } \\
\text { gland }\end{array}$ & $\begin{array}{l}0.77 \pm 0.17 \\
0.53-0.98\end{array}$ & $\begin{array}{l}0.87 \pm 0.34 \\
0.58-1.44\end{array}$ & $\begin{array}{c}0.85 \pm 0.22 \\
(0.49-1.10)\end{array}$ & $\begin{array}{c}0.85 \pm 0.22 \\
(0.51-1.06)\end{array}$ & $\begin{array}{c}0.89 \pm 0.17^{\S} \\
(0.71-1.10)\end{array}$ & $\begin{array}{c}0.92 \pm 0.21 \\
(0.68-1.18)\end{array}$ \\
\hline $\begin{array}{l}\text { Length of left } \\
\text { gland }\end{array}$ & $\begin{array}{c}1.01 \pm 0.14 \\
(0.88-1.23)\end{array}$ & $\begin{array}{c}0.99 \pm 0.28 \\
(0.68-1.32)\end{array}$ & $\begin{array}{l}1.33 \pm 0.23^{\S} \\
(0.96-1.58)\end{array}$ & $\begin{array}{c}1.42 \pm 0.64 \\
(0.90-2.46)\end{array}$ & $\begin{array}{c}1.28 \pm 0.22^{\circ} * \\
(0.98-1.53)\end{array}$ & $\begin{array}{c}1.53 \pm 0.21 \\
(1.39-1.90)\end{array}$ \\
\hline Widht of left gland & $\begin{array}{c}0.66 \pm 0.06 \\
(0.59-0.75)\end{array}$ & $\begin{array}{l}0.55 \pm 0.13^{\mathrm{a}} \\
(0.36-0.69)\end{array}$ & $\begin{array}{l}0.76 \pm 0.17^{\mathrm{a}} \\
(0.55-1.02)\end{array}$ & $\begin{array}{c}0.94 \pm 0.33 \\
(0.52-1.28)\end{array}$ & $\begin{array}{c}0.74 \pm 0.22 \\
(0.51-0.98)\end{array}$ & $\begin{array}{l}0.91 \pm 0.15^{\S} \\
(0.77-1.13)\end{array}$ \\
\hline
\end{tabular}

${ }^{\circ}$ Measured in 4 of 5 calves

$499 \quad{ }^{a}$ Measurements are different $(\mathrm{P}<0.05)$

$500 \S$ First significant difference compared with examination $1(\mathrm{P}<0.05)$

$501 *$ Significant difference compared with right adrenal gland $(\mathrm{P}<0.05)$ 